How to cite: Sârbu, D., Dulău, M., Stănescu, S., Tănase, I., Moldoveanu, M., Gălie, A.C. (2021) Identification and Evaluation of Potential Floodplain Areas Using the Floodplain Evaluation Matrix - Romanian Case Study. 2021 "Air and Water - Components of the Environment" Conference Proceedings, Cluj-Napoca, Romania, p. 105-118, DOI: 10.24193/AWC2021_10.

\title{
IDENTIFICATION AND EVALUATION OF POTENTIAL FLOODPLAIN AREAS USING THE FLOODPLAIN EVALUATION MATRIX - ROMANIAN CASE STUDY
}

\author{
Daniela SÂRBU ${ }^{1}$, Mihaela DULÄU ${ }^{1}$, Stelian STĂNESCU ${ }^{1}$, Ileana TĂNASE ${ }^{1}$,

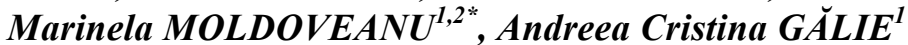

DOI: 10.24193/AWC2021_10

\begin{abstract}
A large number of floodplains got lost due to settlements, infrastructure and agriculture. The reconnection of floodplains plays a significant role considering water retention potential and other aspects such as biodiversity conservation, improvement of water status and river morphology. The delineation and evaluation of potential floodplains and their reconnection capacity require the consideration of the multiple parameters to characterize the effectiveness of floodplains in terms of hydrology/hydraulics, ecology and sociology. In order to delineate floodable area within the lower part of the Desnatui river an unsteady 1D hydrodynamic model has been built up and calibrated, using HEC-RAS software. The Floodplain Evaluation Matrix tool has been applied taking into account the following categories of parameters: hydrology (peak reduction $\Delta \mathrm{Q}$, flood wave translation $\Delta \mathrm{t}$ ), hydraulics (water level $\Delta \mathrm{h}$ ), ecology (connectivity of floodplain water bodies, existence of protected species) and socioeconomics (potentially affected buildings, land use). The results showed that identified floodplain areas have high demand for restoration.
\end{abstract}

Keywords: potential floodplains, Floodplain Evaluation Matrix, lateral connectivity, restoration measures, water retention potential,

\section{INTRODUCTION}

Identification and evaluation of potential floodplain areas have an important role for flood prevention and water quality improvement having in mind important hydrological/hydraulic, ecological and socio-economic aspects.

The role of floodplains in the functioning of aquatic ecosystems and the positive effect on water status are well known. The multiple benefits in terms of increased water retention capacities and flood mitigation represent support for potential winwin solutions for EU Water Framework Directive (EU-Directive 2000/60/EG) and the EU Floods Directive (EU-Directive 2007/60/EC) implementation (EU, 2014).

It is well known that floods are the most relevant natural phenomena that caused dramatic situations due to direct and indirect damage (EEA, 2012; WFD CIS WG,

\footnotetext{
${ }^{1}$ National Institute of Hydrology and Water Management, Şos. București-Ploiești 97E, sector 1, București, 013686, e-mail: daniela.sarbu@hidro.ro

$2 *$ Corresponding author, e-mail: marinela.moldoveanu@hidro.ro
} 
2014; Bussettini et al., 2018). The flood control infrastructures (bank reinforcements/protection, embankments, retention basins, reservoirs with flood attenuation volume etc.) go along with the development of socio-economic systems over time (Hein et al. 2016). Such structures are one of the main causes for hydromorphological alteration and ecological deterioration modifying the hydrological and morphological conditions of rivers by interrupting river continuity (lateral and longitudinal connectivity), modifying the natural erosion and sediment regime and also the connectivity between surface and groundwater. It is known that the flood protection is the second common use for designating Heavily Modified Water Bodies (HMWBs); in the second cycle RBMPs, about 4500 water bodies being designated as HMWBs due to flood control works (WG ECOSTAT, 2020).

As the floodplains preservation and restoration has multiple benefits for flood protection and water quality (Dworak and Görlach 2005) a significant number of measures have been taken in order to improve river lateral connectivity (reconnecting floodplains) within the Danube River Basin District. More than 50,000 ha of floodplains have been partly or totally reconnected and/or their hydrological regime have been improved within the Danube River Basin District. Also, around 150,000 ha were identified to have a reconnection potential and are planned to be reconnected and/or the hydrological regime to be improved (ICPDR, 2015). The next step is the identification of high priority floodplain areas for preservation and/or restoration. Therefore, the evaluation of river floodplains is crucial and requires the consideration of the multiple parameters that objectively characterize the effectiveness of floodplains in terms of hydrology/hydraulics, ecology and sociology (Habersack et al., 2013).

An interdisciplinary method for evaluating river floodplains in the context of integrated flood risk management (Habersack at al., 2013) has been developed within the PRO_Floodplain project (Flood risk reduction by PReserving and restOring river Floodplains) integrating the category of parameters listed above named Flood Evaluation Matrix (FEM). FEM is a multiparameter tool, applicable for different catchment types (Habersack et al. 2008), used to identify and assess the floodplain areas where potential preservation/restoration measures will be most effective in terms of hydrology/hydraulics, ecology and sociology

The FEM method also has been adapted and applied within the Danube Floodplain Project (an on-going project), Romania being the country with two pilot areas: the Bistret lake and the Desnăţui river. Therefore, the paper presents the results of applying the FEM method on the lower part of the Desnăţui River and also the priority for applying restoration measures by ranking the potential floodplains identified.

\section{DATA AND METHODS}

\subsection{Description of the study area}

This study investigated a low-land river namely the Desnăţui River located within the southern part of Romania (Fig. 1), which flows into the Bistret lake. The floodplain areas of the Desnăţui River are large and sinuous downstream of the Fântânele Reservoir having a width from 150 m to 420 m (Ciuinel, 2010). 
Frequent floods are recorded on the Desnăţui River, therefore within the Flood Risk Management Plan of the Jiu River Basin Authority the sector downstream of Fântânele Reservoir was declared Area of Potential Significant Flood Risk in first cycle of the Flood Directive (Flood Risk Management Plans, 2016). Moreover, the Rast - Bistreț area was the subject of a significant flood in 2006 (the flow exceeded Q $1 \%, Q=15.640 \mathrm{~m}^{3} / \mathrm{s}$ at the Bechet gauging station) which caused important social and economic damages.

From administrative point of view, 76 settlements ( 1 urban and 75 rural localities) are located within the Desnăţui River basin with approximately 91,000 inhabitants.

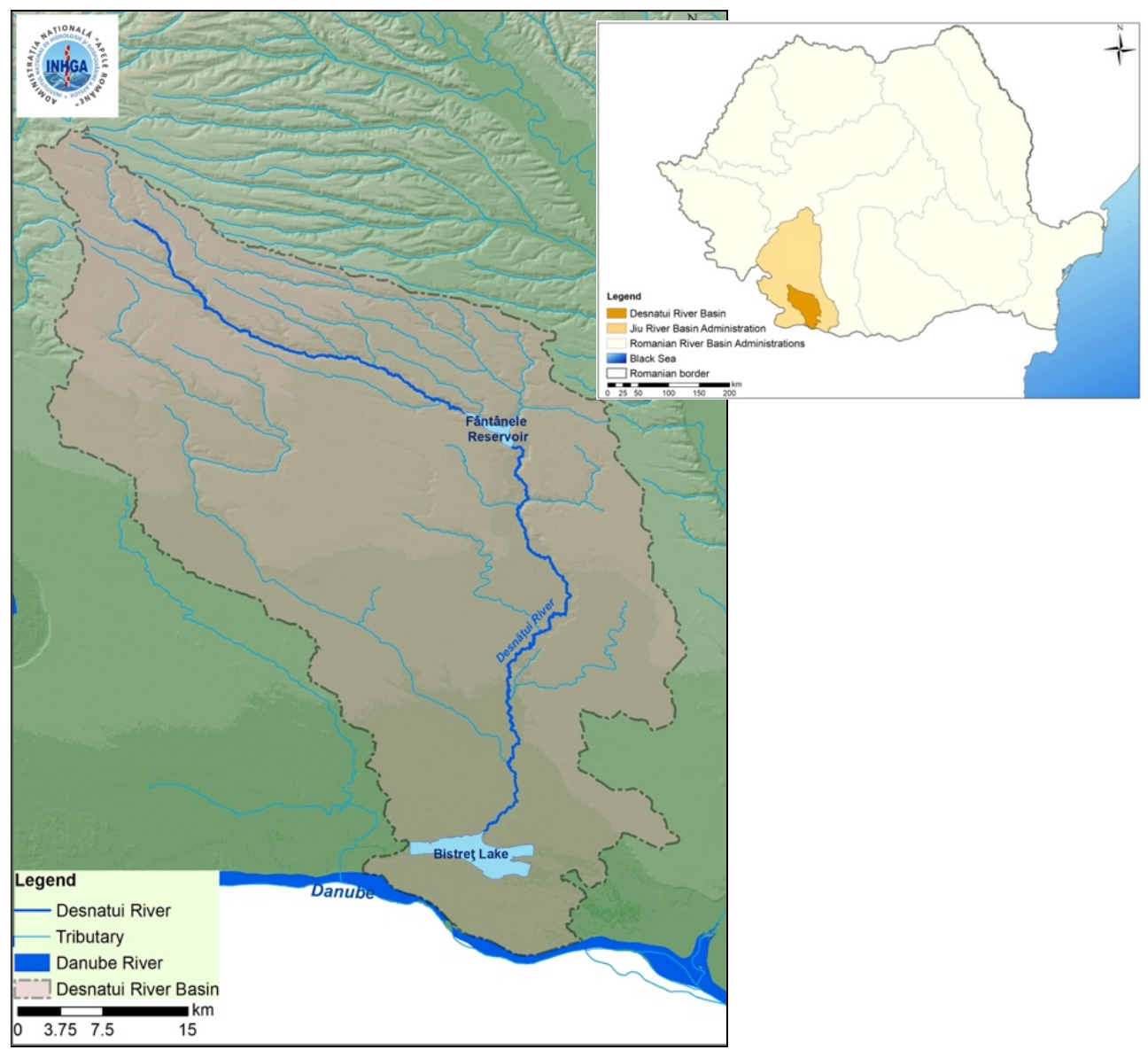

Fig. 1. The location of the Desnăţui river basin within the Jiu River Basin

The study area within the Danube Floodplain project is the lower part of the Desnăţui river, downstream Fântânele Reservoir, with a length of river sector about $62 \mathrm{~km}$ and a catchment area of $1589 \mathrm{~km}^{2}$ (Figure 2). The Fântânele Reservoir, was built primarily to mitigate the floods along the Desnăţui River, mitigating the flood with $1 \%$ probability of occurrence on the surface area of $443 \mathrm{~km}^{2}$. The updated hydrological data (data till 2019, NIHWM database) show the high capacity of 
Fântânele Reservoir to mitigate the flood with probability of occurrence of 100 years, this being almost $93 \%$ (from $280 \mathrm{mc} / \mathrm{s}$ to $20 \mathrm{mc} / \mathrm{s}$ ).

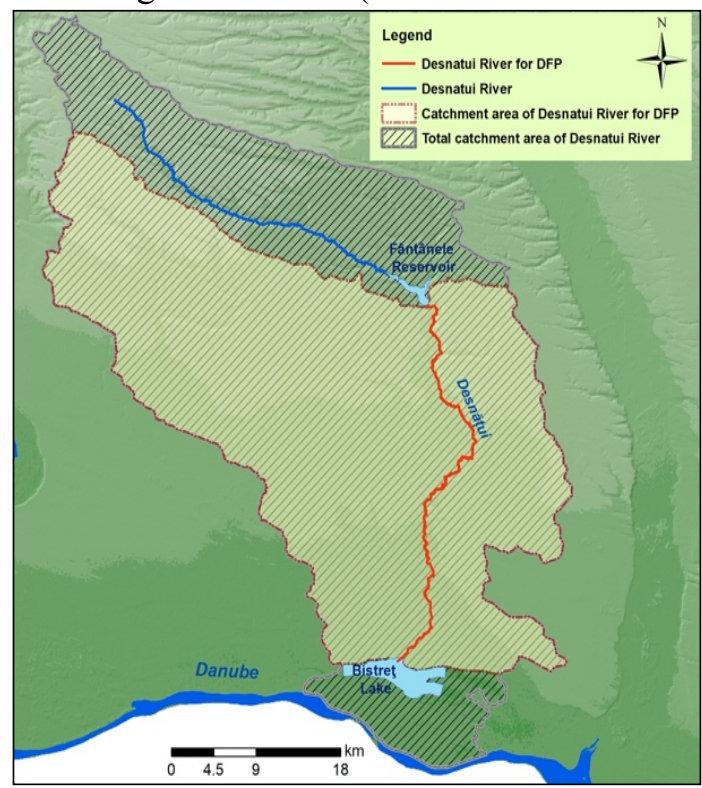

Fig. 2. The study area - the sector of the Desnătui River between the Fântânele Reservoir and the Bistret lake

\subsection{Data used and Methods}

The Floodplain Evaluation Matrix uses 4 categories of parameters and 3 parameter sets (minimum $\square$, medium $\square$, extended $\square$ ) according to the original methodology (Habersack et al. 2008) and adapted within the Danube Floodplain project depending on data availability of each partner project (Table 1).

Table 1. List of final parameters according to FEM methodology

\begin{tabular}{|c|c|c|c|}
\hline Hydromorphology & Hydraulics & Ecology & Socio-Economics \\
\hline peak reduction $(\Delta \mathrm{Q})$ & water level $(\Delta \mathrm{h})$ & connectivity of water bodies & $\begin{array}{c}\text { potentially affected } \\
\text { buildings }\end{array}$ \\
\hline flood wave translation $(\Delta t)$ & $\begin{array}{c}\text { flow velocity } \\
(\Delta \mathrm{v})\end{array}$ & existence of protected species & land use \\
\hline \multirow[t]{5}{*}{$\begin{array}{c}\text { effects (positive/negative) } \\
\text { in case of extreme } \\
\text { discharges }\end{array}$} & \multirow[t]{5}{*}{$\begin{array}{l}\text { bottom shear } \\
\text { stress }\end{array}$} & existence of protected habitats & $\begin{array}{l}\text { presence of documented } \\
\text { planning interest }\end{array}$ \\
\hline & & vegetation naturalness & \\
\hline & & water level dynamics & \\
\hline & & potential for typical habitats & \\
\hline & & $\begin{array}{l}\text { ecological, chemical and } \\
\text { ground water status }\end{array}$ & \\
\hline
\end{tabular}

The threshold ${ }^{3}$ between the values of each parameter has been established and agreed by the Danube Floodplain project partners for the minimum set and are

\footnotetext{
${ }^{3}$ The threshold values for the minimum set of parameters have been harmonized and agreed between the partners of the Danube Floodplain Project.
} 
presented in table 2. In addition, the FEM method has a medium and an extended set of parameters which are optional. The FEM method is a tool for authorities in making the best decisions regarding the measures to be applied.

Table 2. Thresholds for the ranking of parameters - minimum set (1 - low performance, 2 - medium performance, 3 - high performance)

\begin{tabular}{|c|c|c|c|c|c|c|c|}
\hline \multicolumn{2}{|c|}{ Hydromorphology } & \multicolumn{2}{|c|}{ Hydraulics } & \multicolumn{2}{|c|}{ Ecology } & \multicolumn{2}{|c|}{ Socio-Economics } \\
\hline \multicolumn{2}{|c|}{$\Delta \mathrm{Q}$} & \multicolumn{2}{|c|}{$\Delta \mathrm{h}$} & \multicolumn{2}{|c|}{ No. of protected species } & \multicolumn{2}{|c|}{ affected buildings } \\
\hline 1 & $<1 \%$ & 1 & $<10 \mathrm{~cm}$ & 1 & $<40$ & 1 & $>5\left[\mathrm{n} / \mathrm{km}^{2}\right]$ \\
\hline 3 & $1-2 \%$ & 3 & $10-50 \mathrm{~cm}$ & 3 & $40-101$ & 3 & $1-5\left[\mathrm{n} / \mathrm{km}^{2}\right]$ \\
\hline 5 & $>2 \%$ & 5 & $>50 \mathrm{~cm}$ & 5 & $>101$ & 5 & $<1\left[\mathrm{n} / \mathrm{km}^{2}\right]$ \\
\hline \multicolumn{2}{|c|}{$\Delta \mathrm{t}$} & & & \multicolumn{2}{|c|}{$\begin{array}{l}\text { connectivity of water } \\
\text { bodies* }\end{array}$} & \multicolumn{2}{|c|}{ land use } \\
\hline 1 & $<1 \mathrm{~h}$ & & & 1 & Scenario 3 & 1 & $<1$ \\
\hline 3 & $1-4 \mathrm{~h}$ & & & 3 & Scenario 2 & 3 & $2-4$ \\
\hline 5 & $>5 \mathrm{~h}$ & & & 5 & Scenario 1 & 5 & $>4$ \\
\hline
\end{tabular}
above bankfull discharge ( 5 points); S2. Water bodies connected at mean water level up to bankfull discharge ( 3 points); S3. Water bodies not connected above bankfull discharge / On the historic maps "natural" (historic) water bodies existed, but at the potential floodplain no water bodies are left (1 point

In order to apply the Floodplain Evaluation Matrix in case of the Desnăţui River, an unsteady 1D hydrodynamic model was built up for the river sector between the Fântânele Reservoir and the Bistreţ Lake (a river sector about $60 \mathrm{~km}$ in length) using HEC-Ras software, using as input data measured cross-sections profiles and LIDAR DTM obtained at the level of 2011, for generating the flood limit for different probability of exceeding.

The calibration of the hydraulic model aimed that the calculated levels at the gauging stations for the maximum flows corresponding to the flood volume transported through both the channel and floodplain, to overlap the levels indicated from the rating curve of the respective gauging stations. The model was calibrated with good results in particular using the existing rating curve at the Goicea gauging station - the Desnăţui River (see figure 3).

Mainly, this calibration has been performed by adjusting the values of the coefficients of Manning roughness from channels. The values of the roughness coefficients, adopted in accord with „HEC - RAS - River Analysis System Hydraulic Reference Manual" recommendation, taking into account the characteristics of the study area and based on ortho-photo plans varied between 0.035 and 0.04 in river channel and between 0.065 and 0.070 in floodplains.

The downstream boundary condition used in the hydraulic model was considered the normal depth and the actual slope of the Desnăţui River in the downstream area, which is less than $1 \%$.

In order to evaluate the potential floodplains of the Desnăţui River by applying the Floodplain Evaluation Matrix - minimum set (Table 1), first has been made the delineation of potential floodplains taking into account the following criteria: (i) the 
values of the ratio factor of width floodplain/width river $>2: 1$, (ii) the area of each floodplain to be larger than 100 ha.

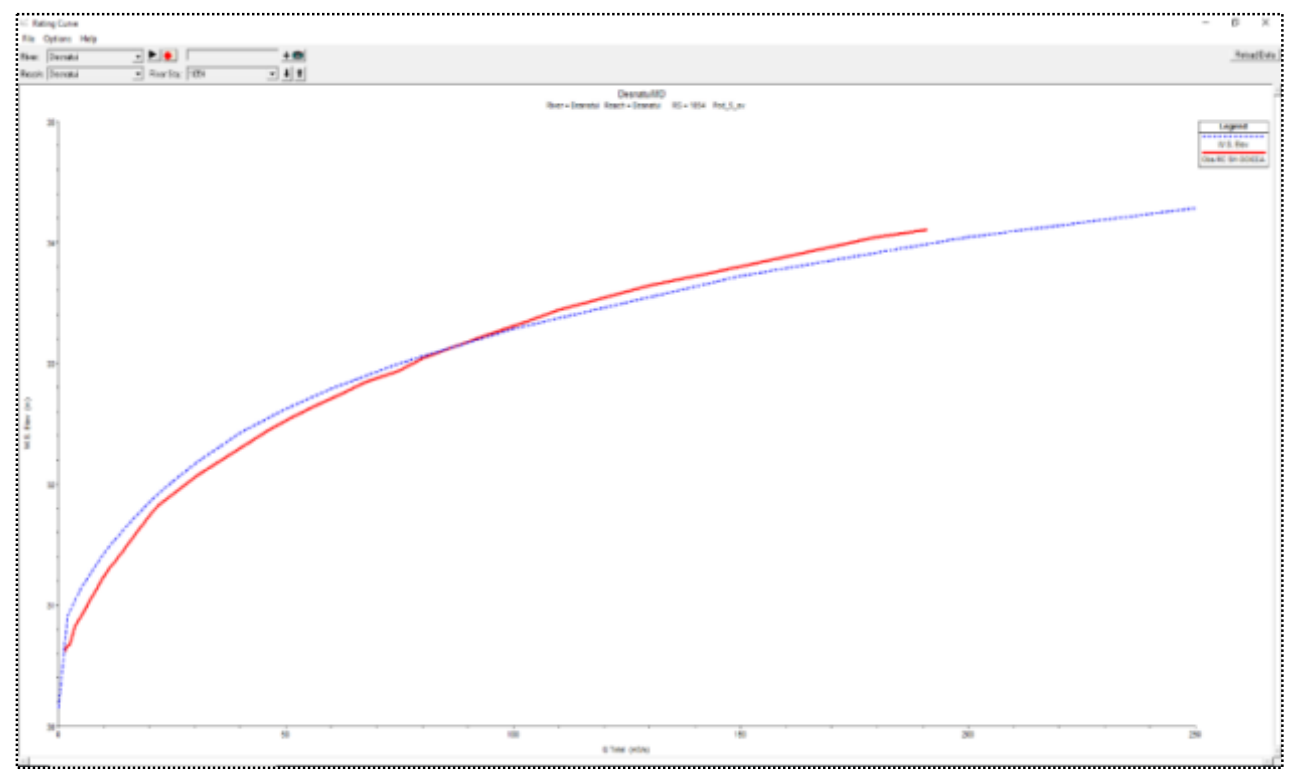

Fig. 3. The measured/calculated rating curve at the Goicea gauging station from the Desnațui River

The flood limit for the probability of a flood occurring once every 200 years was recommended to be used within the hydrological models, for the purpose of the evaluation of the FEM the methodology, for delineation of potential floodplains.

\section{RESULTS AND DISCUSSION}

Three potential floodplains (Figure 4) for the Desnăţui River (RO_Desnatui_pFP_01, RO_Desnatui_pFP_02, RO_Desnatui_pFP_03) having more than 100 ha area each one, have been delineated and evaluated using the described methodology.

In order to evaluate and rank the potential floodplains, all of the FEM parameters from the minimum set listed within the table 1 , have been applied. The following paragraphs are explaining the description of each parameter, source of data and the workflow.

\subsection{Flood peak reduction $(\Delta Q)$}

To evaluate the peak reduction for a floodplain, the peak of an input hydrograph at the beginning of the floodplain and the peak of the output hydrograph at the end of the floodplain were determined. The difference between the two peaks is the peak reduction $\Delta \mathrm{Q}_{\text {tot }}\left[\mathrm{m}^{3} / \mathrm{s}\right]$ for the investigated floodplain.

It was also taken into account the retention/storage effect of the river channel. Therefore, the peak reduction $\Delta \mathrm{Q}_{\mathrm{RC}}\left[\mathrm{m}^{3} / \mathrm{s}\right]$ of the river channel has been modelled 
considering fictive dykes meaning the floodplains were disconnected from the river channel.

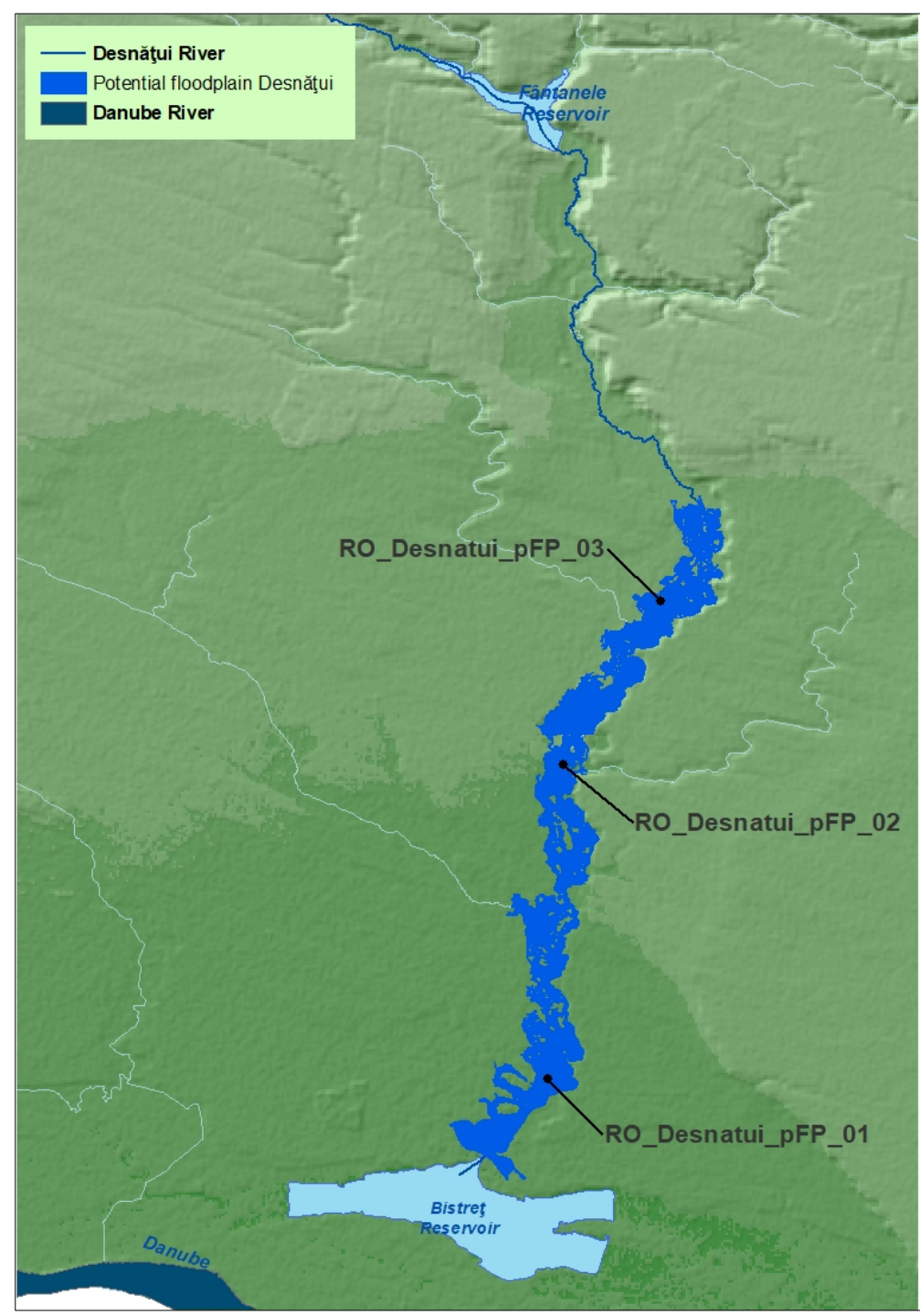

Fig. 4. The potential floodplains delineated on the Desnăţui River

For demonstrating only, the effect of the floodplains on the peak reduction $(\Delta \mathrm{Q})$ $\Delta \mathrm{Q}_{\mathrm{RC}}$ was subtracted from the $\Delta \mathrm{Q}_{\mathrm{tot}}$.

The results of the unsteady hydrodynamic-numerical 1D-simulations were used for the determination of the peak reduction. The $\Delta \mathrm{Q}$ and $\Delta \mathrm{t}$ were identified for the modeled floodable areas and for the flooded areas. Using the FEM guide ${ }^{4}$ the level

\footnotetext{
${ }^{4}$ The FEM guide was developed within the Danube Floodplain project
} 
of attenuation and propagation time were observed on different cross sections, as shown in the Figure 5.

The analysis shows that the mitigation along the river, for floodable areas, when taking into account important inflows from tributaries, the peak reduction is maximum $0.5 \%$.

\subsection{Flood wave translation}

This parameter is determined in a similar way as the peak reduction, namely by calculating the time difference $\Delta \mathrm{t}[\mathrm{h}]$ between the occurrence of the output/input hydrograph peak.

The results of the unsteady hydrodynamic-numerical 1D-simulations were used for the determination of the flood wave translation.
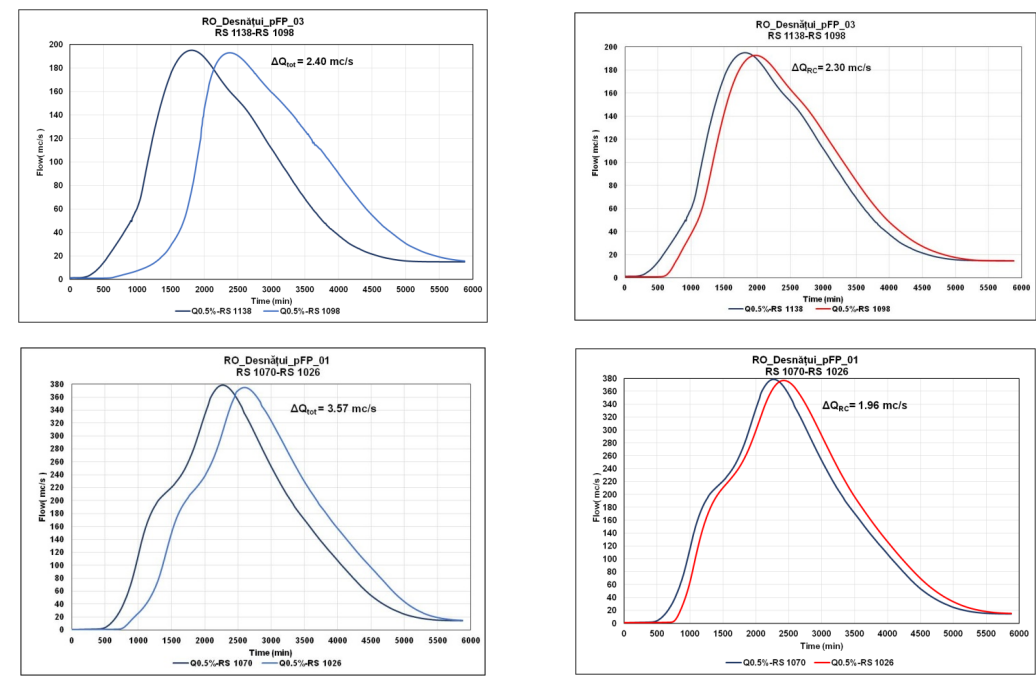

a) $\Delta \mathrm{Q}_{\text {tot }}$

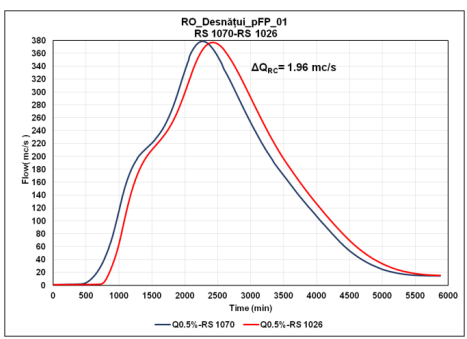

b) $\Delta \mathrm{Q}_{\mathrm{RC}}$

Fig. 5. Examples of attenuation and propagation time in different cross sections

In terms of propagation time, the major impact can be considered on the RO_Desnatui_pFP_03 area where more than $2 \mathrm{~m}^{3} / \mathrm{s}$ attenuation occurs in $570 \mathrm{~min}$, as it is shown in the Figure 6.

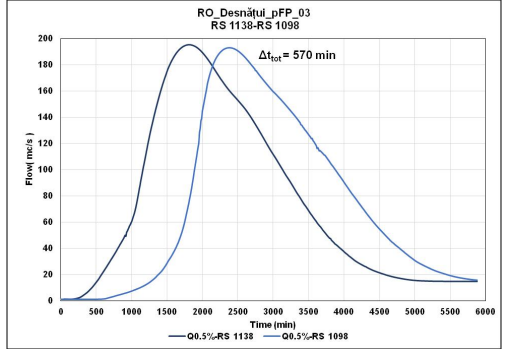

a) for $\Delta t_{\text {tot }}$

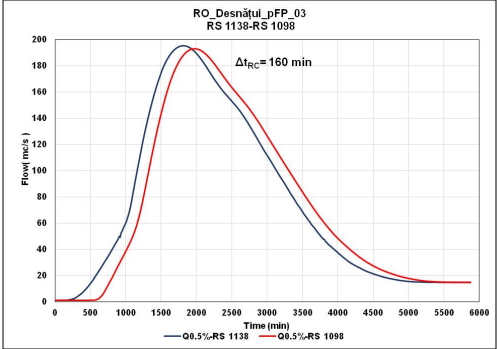

b) for $\Delta t_{R C}$

Fig. 6. The examples for flood wave translation $(\Delta t)$ 


\subsection{Water level}

This parameter demonstrates the effects of a total loss of a floodplain on the water level. The values are calculated in a cross section chosen in the middle of the floodplain or in the area of a settlement.

The following steps have been applied:

Step 1: To compute water level for a $H Q_{200}$ with the potential floodplain $\left(h_{t o t}\right)$

Using the same hydrodynamic-numerical calculation which was used to determine the hydrological parameters $\left(\Delta \mathrm{Q}_{\mathrm{tot}}\right.$ and $\left.\Delta \mathrm{t}_{\mathrm{tot}}\right)$, in a defined cross-section, the calculated water level $\mathrm{h}_{\text {tot }}$ in the middle of the river channel was calculated.

Step 2: To compute water level for a $H Q_{200}$ without floodplain $\left(h_{R C}\right)$

Using the same hydrodynamic-numerical calculation, which was used to determine the hydrological parameters $\left(\Delta \mathrm{Q}_{\mathrm{RC}}\right.$ and $\left.\Delta \mathrm{t}_{\mathrm{RC}}\right)$ the water level $\left(\mathrm{h}_{\mathrm{RC}}\right)$ was calculated in the same location as in step 1 .

Step 3: To compute the $\Delta h$

The value for $\Delta_{\mathrm{h}}$ was obtained subtracting the calculated water level without floodplains $\left(\mathrm{h}_{\mathrm{RC}}\right)$ from the water level $\left(\mathrm{h}_{\mathrm{tot}}\right)$, for each potential floodplain.

\subsection{Connectivity of floodplain water bodies}

Connectivity is crucial for the functioning of riverine ecosystems. The longitudinal connectivity describes the connectivity in the upstream and downstream direction and is especially relevant for the exchange of populations of water organisms and their migration during their life cycle.

The lateral connectivity refers to the connection of the river channel and the floodplain and the vertical connectivity is the connection of the river channel and the ground water table in the floodplain (which might be crucial for small temporary water bodies in the floodplain).

In this case, the performance (see table 2) is derived directly, taking into account 3 scenarios:

1. Water bodies connected up to mean water level / No "natural" (historic) water bodies on the floodplain / meandering river systems connected above bankfull discharge (5 points)

2. Water bodies connected at mean water level up to bankfull discharge (3 points)

3. Water bodies not connected above bankfull discharge / On the historic maps "natural" (historic) water bodies existed, but at the potential floodplain no water bodies are left (1 point)

If water bodies are cut off by a dyke but still exist on the floodplain, it will lead to a downgrade into the next FEM-class:

E. g. Water bodies are connected up to mean flow $\rightarrow 5$ points and in addition, the historic maps showed that the existing water bodies were cut off; this leads to a downgrade into the next class: 3 points.

Following an analysis of the 3 scenarios, the selected scenario was Scenario 2 (bankfull flow) for all potential floodplain.

The condition: "If the river system is meandering, the connectivity is naturally beginning at bankfull discharge" was demonstrated using the unsteady 1D model 
and verified for scenario "Water bodies connected up to mean water level / No "natural" (historic) water bodies on the floodplain / meandering river systems connected above bankfull discharge".

This applies for all analyzed floodplains. The potential floodplains were evaluated with 3 points according to the FEM evaluation procedure.

\subsection{Existence of protected species}

A floodplain is valuable and should be preserved if protected species and habitats (recognized by Natura 2000 or other directive) exist in the area.

In order to calculate this parameter, the Natura 2000 database and the results of the fauna and habitats monitoring campaigns carried out in accordance with Art. 12 of the Birds Directive and Art. 17 of the Habitats Directive have been used.

In order to have a clear picture of the flora and fauna of the floodplains, two main sources of information were used: the Natura 2000 Standard Forms of the Natura 2000 sites intersected by the potential floodplains and, because some of the floodplains did not intersect any Natura 2000 sites, the need of a second source of information arisen; therefore, the results of the fauna and habitats monitoring campaigns carried out in accordance with Art. 12 of the Birds Directive and Art. 17 of the Habitats Directive were used (available on: http://www.mmediu.ro/articol/date-gis/434).

The shapefile with information about protected species and habitats was overlapping with areas delineated as potential floodplains, along the Desnăţui River, and these are not located in protected areas (see Figure 7).

Still, results of the fauna and habitats monitoring campaigns have one major limitation: they describe the species present in a $1 \mathrm{~km} \times 1 \mathrm{~km}$ square that, in certain cases exceeds the limits of the floodplain and some species may be present in the square but not necessarily in the floodplain area. Due to the fact that the elimination of some species can be subjective, the list of species was kept intact based mostly on expert opinion.

Nevertheless, this generates another issue: the total number of species present in an area designated for implementation of restoration measures is a good indicator only of all the species could benefit from the measures. Still, some species require, for example dry pastures or sandy dunes which could be flooded and, therefore, lost.

\subsection{Potentially affected buildings}

Nowadays, in Romania, the process of registering all real estate in the Integrated Cadaster and Land Book System at national level is in progress. Thus, to determine this parameter, were used the available orthophoto plans from 2012-2016.

All the parameters have been calculated according to FEM methodology and the results were compared with the defined thresholds (Table 2) and then, using the ranking, the FEM evaluation for each potential floodplain was done (Table 3 ). 


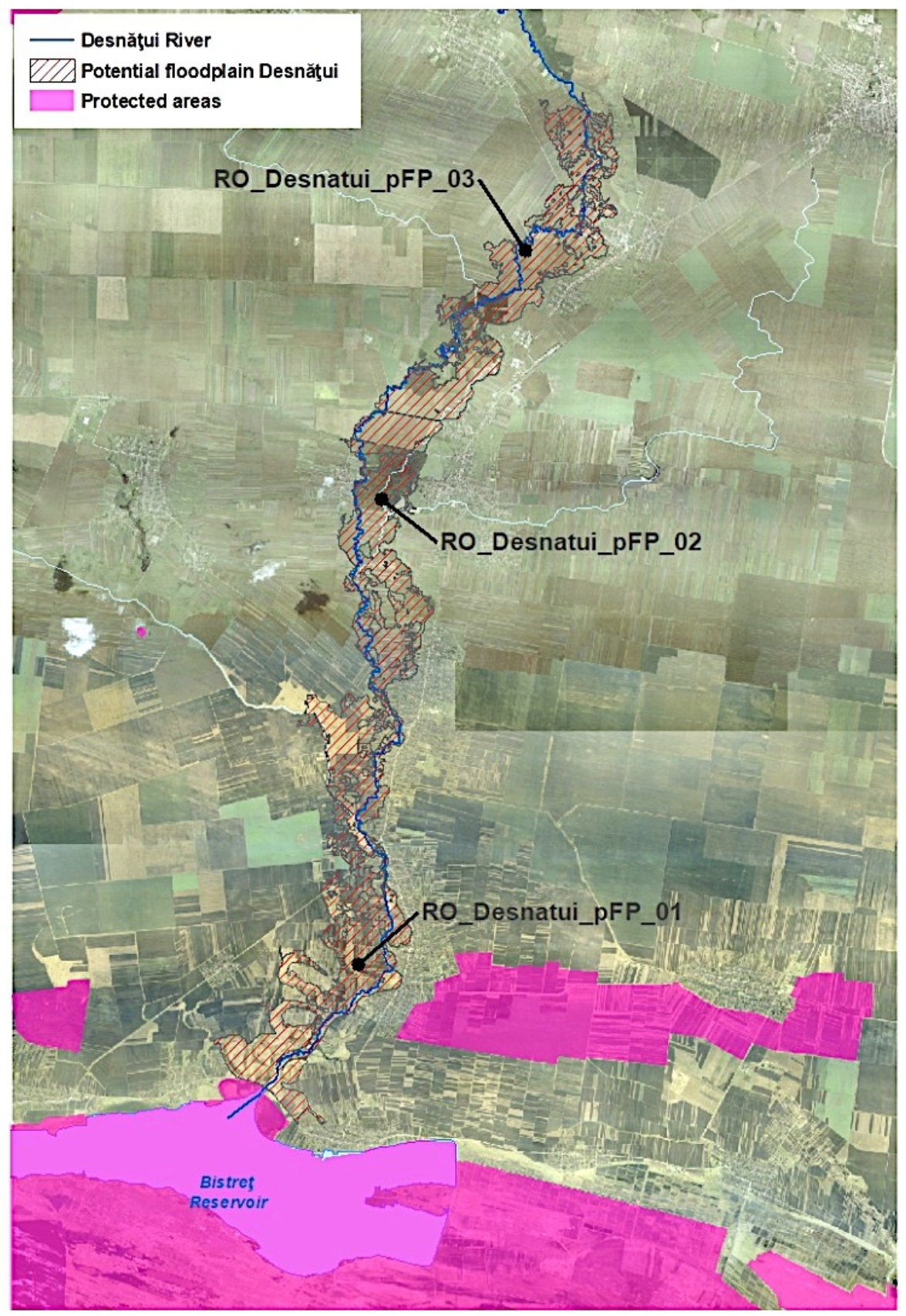

Fig. 7. The location of protected areas along the Desnăţui River

\subsection{Land use}

Evaluation of this parameter was done using CORINE land cover dataset. To obtain results for this parameter a statistical analysis was accomplished for each land use class. 
Table 3. The results of FEM evaluation for potential floodplains of Desnățui River

\begin{tabular}{|c|c|c|c|c|c|c|c|c|c|c|c|c|c|c|c|c|c|c|c|c|c|c|c|}
\hline \multirow{3}{*}{$\begin{array}{l}\overrightarrow{0} \\
\stackrel{0}{0} \\
\stackrel{0}{0} \\
\overrightarrow{0} \\
\stackrel{0}{0} \\
\overrightarrow{0} \\
\stackrel{0}{0} \\
\frac{0}{0} \\
\stackrel{0}{0} .\end{array}$} & \multicolumn{9}{|c|}{ Hydrology } & \multicolumn{4}{|c|}{ Hydraulics } & \multicolumn{4}{|c|}{ Ecology } & \multicolumn{6}{|c|}{ Socio-Economics } \\
\hline & \multicolumn{5}{|c|}{$\begin{array}{l}\text { Peak reduction } \\
\qquad\left(\mathrm{m}^{3} / \mathrm{s}\right)\end{array}$} & \multicolumn{4}{|c|}{$\begin{array}{l}\text { Flood wave } \\
\text { translation } \\
\quad(\mathrm{min})\end{array}$} & \multicolumn{4}{|c|}{$\begin{array}{l}\text { Water level } \\
\text { (m) }\end{array}$} & \multicolumn{2}{|c|}{$\begin{array}{l}\text { Connectivity } \\
\text { of floodplair } \\
\text { water bodies }\end{array}$} & \multicolumn{2}{|c|}{$\begin{array}{l}\text { Existence } \\
\text { of } \\
\text { protected } \\
\text { species }\end{array}$} & \multicolumn{4}{|c|}{$\begin{array}{l}\text { Potentially affected } \\
\text { buildings }\end{array}$} & \multicolumn{2}{|c|}{ Land us } \\
\hline & 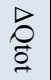 & $2 \underset{0}{2}$ & $b$ & ๑) & $\frac{7}{3}$ & $\stackrel{\gtrless}{\stackrel{\Xi}{\rightleftarrows}}$ & $2 \stackrel{\unrhd}{\emptyset}$ & $\gtrsim$ & $\pi_{\pi}^{*}$ & $\stackrel{\bar{\sigma}}{\circ}$ & 坖 & $\gtrless$ & $\begin{array}{l}\frac{7}{17} \\
3\end{array}$ & 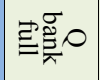 & $\begin{array}{l}\frac{\pi}{\pi} \\
3 \\
3\end{array}$ & 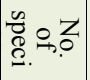 & 等 & :웅 & $\sum_{n} \infty$ & 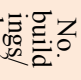 & $\frac{\pi}{3}$ & . & $\begin{array}{l}\frac{7}{7} \\
3 \\
3\end{array}$ \\
\hline \begin{tabular}{|c|} 
RO \\
Desnăţu \\
$\mathrm{pFP}_{-} 0$
\end{tabular} & 3.57 & 71.96 & 1.61 & $10.45^{\circ}$ & 1 & 34 & 0160 & 180 & 3 & 32. & 840.7 & 8.0 & 5 & $\begin{array}{l}7.1 \mathrm{mc} / \\
<\mathrm{Q} 50^{\circ}\end{array}$ & 3 & 57 & 3 & 173 & 11.5 & 15.1 & 1 & 3.00 & 3 \\
\hline \begin{tabular}{|c|} 
RO \\
Desnăţu \\
pFP_02
\end{tabular} & 1.34 & 41.05 & 0.29 & $90.13 \%$ & 1 & 231 & 0100 & 130 & 3 & 45. & .450 .8 & 5.3 & 5 & $\begin{array}{l}4.3 \mathrm{mc} / \\
<\mathrm{Q} 50 \%\end{array}$ & 3 & 18 & 1 & 3 & 6.78 & 0.4 & 5 & & 3 \\
\hline \begin{tabular}{|c|} 
RO \\
Desnăţu \\
pFP_03
\end{tabular} & 2.40 & 02.30 & 0.10 & $09.07^{\circ}$ & 1 & 57 & 0160 & 410 & 5 & & 166.4 & 8.3 & 5 & $\begin{array}{l}77.7 \mathrm{mc} / \\
\approx \mathrm{Q} 20 \%\end{array}$ & 3 & 13 & 1 & 38 & 9.02 & 4.2 & 3 & 3.40 & 3 \\
\hline
\end{tabular}

Most of the analyzed parameters for all three potential floodplains delineated received low and medium performance. According to the score of each parameter, the final ranking has been done and the potential floodplains demand for restoration measures have been established (Table 4).

Therefore, all the identified potential floodplains have the highest priority for restoration measures.

Table 4. The results of FEM evaluation for potential floodplains of the Desnăţui River and the final ranking

\begin{tabular}{|c|c|c|c|c|c|c|c|c|c|}
\hline \multirow{2}{*}{$\begin{array}{l}\text { Potential } \\
\text { floodplain }\end{array}$} & \multicolumn{2}{|c|}{ Hydrology } & $\begin{array}{l}\text { Hydra } \\
\text { ulics }\end{array}$ & \multicolumn{2}{|c|}{ Ecology } & \multicolumn{2}{|c|}{$\begin{array}{c}\text { Socio- } \\
\text { Economics }\end{array}$} & \multirow{2}{*}{$\begin{array}{c}\text { Final } \\
\text { ranking }\end{array}$} & \multirow{2}{*}{$\begin{array}{l}\text { Restoration } \\
\text { demand }\end{array}$} \\
\hline & 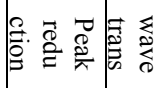 & $=\frac{\pi}{8}$ & $\begin{array}{l}\sum_{0}^{0} \\
\frac{1}{2}\end{array}$ & p. 导 § & 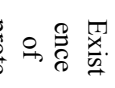 & 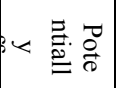 & है & & \\
\hline RO_Desnatui_PFP0 & 1 & 3 & 5 & 3 & 3 & 1 & 3 & 19 & $\begin{array}{l}\text { high } \\
\text { demand }\end{array}$ \\
\hline RO_Desnatui_PFP0 & 1 & 3 & 5 & 3 & 1 & 5 & 3 & 21 & $\begin{array}{l}\text { high } \\
\text { demand }\end{array}$ \\
\hline $\mathrm{RO}_{3}$ _Desnatui_PFP0 & 1 & 5 & 5 & 3 & 1 & 3 & 3 & 21 & $\begin{array}{l}\text { high } \\
\text { demand }\end{array}$ \\
\hline
\end{tabular}

According to the results of the FEM Floodplain evaluation and ranking, for the delineated potential floodplains, all PFP were establish into high demand (Restoration priority) category, there some measures (in dependence of the national capacities) for the status improvement should be considered for PFP are in less favorable category. 


\section{CONCLUSIONS}

The paper presents the results of applying the FEM method on the Desnăţui River based on an unsteady 1D hydrodynamic model (built up and calibrated).

According to FEM results three potential floodplains have been identified, evaluated and ranked using the methodology developed in the Danube Floodplain project.

The FEM results show that the identified potential floodplains of the Desnăţui River have the highest priority for restoration measures. Therefore, in case of Desnaţui River could be implemented some structural restoration measures like dikes relocation in the confluent area of Desnaţui River with Bistret Lake, creation of a large water drainage channel to supply Lake Bistret and to facilitate the natural flow of Desnaţui River back in the Danube or non-structural measures.

FEM can be adapted and applied in case of other river basins in Romania in order to identify the potential floodplain and to improve river lateral connectivity (hydrological regime improvement).

\section{ACKNOWLEDGEMENTS}

This work was performed within Danube Floodplain - Reducing the flood risk through floodplain restoration along the Danube River and tributaries, project cofunded by the European Union (Danube Transnational Programme). We thank the University of Natural Resources and Life Sciences from Vienna for coordinating the application of FEM among project partners, including methodological frame for the identification, delineation, evaluation, classification and ranking of the floodplains.

\section{REFERENCES}

1. Bussettini M, Kling J, van de Bund, W. (2018), Working Group ECOSTAT report on common understanding of using mitigation measures for reaching Good Ecological Potential for heavily modified water bodies - Part 2: Impacted by flood protection structures, EUR 29131 EN; Publications Office of the European Union, Luxembourg, ISBN 978-92-79-80290-4, doi:10.2760/875939, JRC110957.

2. Ciuinel, A. M. (2010), Efectele acumulării Fântânele asupra dinamicii reliefului şi a albiei minore a râului Desnăţui, Conference proceedings "Water resources and wetlands" 2010, p. 417-420.

3. Dworak T, Görlach B (2005) Flood risk management in Europe - the development of a common EU policy. Int J River Basin Manag 3(2):97-103.

4. European Commission (2014) - EU policy document on Natural Water Retention Measures By the drafting team of the WFD CIS Working Group Programme of Measures (WG PoM) (https://climate-adapt.eea.europa.eu/metadata/guidances/eu-policy-documenton-natural-water-retention-measures/11309347).

5. European Environment Agency (2012), River floods. Available online: http://www.eea.europa.eu/data-andmaps/indicators/river-floods-1/assessment.

6. European Environment Agency (2016), Flood risks and environmental vulnerability. Exploring the synergies between floodplain restoration, water policies and thematic policies (Available online: https://www.eea.europa.eu/publications/flood-risks-andenvironmental-vulnerability/file). 
7. European Environment Agency (2018), European waters. assessment of status and pressures 2018. EEA report 7/2018. Luxembourg: Publications Office of the European Union (Available online: https://www.eea.europa.eu/publications/state-of-water).

8. Habersack, H, Hauer C, Schober, B, Dister E, Quick, I, Harms, O, Wintz, M, Piquette, E, Schwarz, U, (2008) Flood risk reduction by preserving and restoring river floodplains (PRO_Floodplain)_Final Report. Era-Net CRUE 1st Call. Era-Net CRUE, EU.

9. Habersack, H., Schober, B., Hauer, C. (2013), Floodplain evaluation matrix (FEM): An interdisciplinary method for evaluating river floodplains in the context of integrated flood risk management. Natural Hazards, doi:10.1007/s11069-013-0842-4.

10. Hein T, Schwarz U, Habersack H, Nichersu I, Preiner S, Willby N, Weigelhofer G (2016) Current status and restoration options for floodplains along the Danube River. Sci Total Environ 543:778-790.

11. ICPDR (2015), The Danube River Basin District Management Plan

12. WFD CIS Working Group on Floods (2014), Links between the Floods Directive (FD2007/60/EC) and Water Framework Directive (WFD 2000/60/EC) Technical report 078/2014.

13. WFD CIS working group ECOSTAT (2020), Guidance No 37 - Steps for defining and assessing ecological potential for improving comparability of Heavily Modified Water Bodies.

14. http://www.mmediu.ro/articol/date-gis/434

15. ***Danube Floodplain project, Floodplain assessment on selected tributaries - Floodplain Report Desnăţui River (2020).

16. *** Flood Risk Management Plans, 2016

17. ***NIHWM database

18. *** HEC - RAS - River Analysis System - Hydraulic Reference Manual 